Article

\title{
Copper Complexing Capacity and Trace Metal Content in Common and Balsamic Vinegars: Impact of Organic Matter
}

\author{
Sotirios Karavoltsos ${ }^{1, *}$, Aikaterini Sakellari ${ }^{1}$, Vassilia J. Sinanoglou ${ }^{2}$, \\ Panagiotis Zoumpoulakis ${ }^{3}{ }^{(\mathbb{D}}$, Marta Plavšić ${ }^{4}$, Manos Dassenakis ${ }^{1}$ and Nick Kalogeropoulos ${ }^{5}$ (i) \\ 1 National and Kapodistrian University of Athens, Department of Chemistry, Laboratory of Environmental \\ Chemistry, Panepistimiopolis, Zografou, 15784 Athens, Greece; esakel@chem.uoa.gr (A.S.); \\ edasenak@chem.uoa.gr (M.D.) \\ 2 University of West Attica, Department of Food Science and Technology, Laboratory of Chemistry, Analysis \& \\ Design of Food Processes, Agiou Spiridonos 28, Egaleo 122 43, Greece; vsina@uniwa.gr \\ 3 Institute of Chemical Biology, National Hellenic Research Foundation, 48, Vas. Constantinou Ave., 11635 \\ Athens, Greece; pzoump@eie.gr \\ 4 Ruđer Bošković Institute, Division for Marine and Environmental Research, P.O. Box 180, 10002 Zagreb, \\ Croatia; plavsic@irb.hr \\ 5 Harokopio University of Athens, Department of Dietetics-Nutrition, School of Health Science and Education, \\ El. Venizelou 70, Kallithea, 17676 Athens, Greece; nickal@hua.gr \\ * Correspondence: skarav@chem.uoa.gr; Tel.: +30-210-7274049
}

Academic Editor: Derek J. McPhee

Received: 26 January 2020; Accepted: 14 February 2020; Published: 15 February 2020

\begin{abstract}
Complex formation is among the mechanisms affecting metal bioaccessibility. Hence, the quantification of organic metal complexation in food items is of interest. Organic ligands in solutions of environmental and/or food origin function as buffering agents against small changes in dissolved metal concentrations, being able to maintain free metal ion concentrations below the toxicity threshold. Organic matter in vinegars consists of bioactive compounds, such as polyphenols, Maillard reaction endproducts, etc., capable of complexing metal ions. Furthermore, transition metal ions are considered as micronutrients essential for living organisms exerting a crucial role in metabolic processes. In this study, differential pulse anodic stripping voltammetry (DPASV), a sensitive electrochemical technique considered to be a powerful tool for the study of metal speciation, was applied for the first time in vinegar samples. The concentrations of $\mathrm{Cu}$ complexing ligands $\left(L_{\mathrm{T}}\right)$ in 43 vinegars retailed in Greece varied between 0.05 and $52 \mu \mathrm{M}$, with the highest median concentration determined in balsamic vinegars $(14 \mu \mathrm{M})$, compared to that of common vinegars $(0.86 \mu \mathrm{M})$. In $21 \%$ of the vinegar samples examined, $L_{\mathrm{T}}$ values were exceeded by the corresponding total $\mathrm{Cu}$ concentrations, indicating the presence of free $\mathrm{Cu}$ ion and/or bound within labile inorganic/organic complexes. Red grape balsamic vinegars exhibited the highest density of $\mathrm{Cu}$ ligands per mass unit of organic matter compared to other foodstuffs such as herbal infusions, coffee brews, and beers. Among the 16 metals determined in vinegars, $\mathrm{Pb}$ is of particular importance from a toxicological point of view, whereas further investigation is required regarding potential $\mathrm{Rb}$ biomagnification.
\end{abstract}

Keywords: copper complexation; organic ligands; trace metals; vinegars

\section{Introduction}

Vinegars are one of the few acidic condiments used as a flavoring agent, preservative and, in some countries, a healthy drink [1,2]. Wine vinegar is made from red or white wine and is the most widely used vinegar in the households of Mediterranean and Central Europe countries [3]. Vinegars 
are classified as "common" or "balsamic" according to their production from either wine or cooked grape must fermentation, respectively [4]. In the European Union, established limits for acidity are strictly specified. Thus, the acidity of wine vinegar (acetification obtained exclusively from wine) must be at least $6 \% w / v[5]$.

The fraction of metals which can actually be retained by the human body through vinegar consumption is related to the levels of metals in the harvest (primarily metals in grape juice and wine) as well as metal impurities due to manufacturing processes (chemicals added during production, materials used during transport, processing, or storage) [6] in addition to the bioavailability of metal species present in vinegar [7]. Metal bioaccessibility is affected by several natural mechanisms, among which complex formation is included. Additionally, due to hydrogen atom transfer and single-electron transfer, phenolic antioxidants protect against free radical formation by binding and/or inactivating metal ions [8-10]. Such a mechanism of antioxidant action is quite significant, despite the fact that the contribution of free radical scavenging or metal chelation to the overall antioxidant activity is still not fully specified [11].

It is well known that several toxic and/or biological effects of metals are attributed to their free or labile forms, which can actively interact with the binding sites of biological ligands $[12,13]$. The most labile form is the free dissolved metal ions, $\mathrm{Me}^{\mathrm{x}+}$ (usually present as hydrated species), followed by dissolved inorganic metal ion pairs and complexes and organic complexes [14]. Differential pulse anodic stripping voltammetry (DPASV) is one of the few sensitive electrochemical techniques able to provide information on metal lability [15]. Typically, at low $\mathrm{pH}$ values, metal ions are present as the most labile species (as free ions or inorganic complexes) and are prone to different interactions [16].

Vinegars, depending on the raw material, origin, and type, are characterized by the presence of significant amounts of organic material composed by polyphenols, aminoacids, Maillard reaction endproducts, etc., prone to complexing metals and simultaneously representing the acidic matrix attributed to the presence of acetic acid. In such an environment, the study of metal complexation, for which available pertinent information is lacking, becomes challenging.

Due to the fact that vinegars - being a dilute acetic acid solution-accelerate rusting, their content of trace elements turns out to be of particular interest. The reaction of acetate with chemical species (moieties) present in rust and grimes changes their makeup, hence resulting in their dissolution into water $[17,18]$. Although there are numerous published works on the concentrations of metals in wine, only a few refer to metal concentrations in vinegar [3,6,19-21].

Therefore, the objectives of the present study were (a) to evaluate the occurrence of ligands prone to complexing $\mathrm{Cu}$ ions, thereby "buffering" the concentrations of free metal ions, in cases where pertinent available data are lacking and (b) to determine 16 trace element concentrations of vinegars retailed in Greece. The interaction of $\mathrm{Cu}$ chemical speciation with bioactive compounds present in vinegars is also discussed.

\section{Results and Discussion}

Organic carbon (OC) concentrations in the vinegar samples examined ranged from 17 to 278 $\mathrm{mg} \mathrm{L}^{-1}$ (Table 1 ), with balsamic vinegars demonstrating a significantly higher, approximately 5 -fold, median OC content $\left(152 \mathrm{mg} \mathrm{L}^{-1}\right)$ than common vinegars $\left(30 \mathrm{mg} \mathrm{L}^{-1}\right)$ (Mann-Whitney test, $p<0.001$ ). It is noteworthy that none of the common vinegars analyzed had an OC that exceeded $50 \mathrm{mg} \mathrm{L}^{-1}$, whereas in the balsamic vinegars, the lowest measured concentration was equal to $90 \mathrm{mg} \mathrm{L}^{-1}$ (Table 1). 
Table 1. Copper complexation parameters $\left(L_{\mathrm{T}}, \log K_{\text {app }}\right)$, total $\mathrm{Cu}$ concentration, organic carbon content, $\mathrm{pH}$, and $L_{\mathrm{T}} / \mathrm{TOC}$ values in different categories of vinegars.

\begin{tabular}{|c|c|c|c|c|c|c|c|}
\hline Sample No & Vinegars & $\mathrm{pH}$ & $L_{\mathrm{T}}(\mu \mathrm{M})$ & $\log K_{a p p}$ & $\mathrm{Cu}(\mu \mathrm{M})$ & OC $\left(\mathrm{mg} \mathrm{L}^{-1}\right)$ & $\begin{array}{c}L_{\mathrm{T}} / \mathrm{OC}(\mathrm{nmol} \\
\left.\mathrm{Cu} \mathrm{mg}^{-1} \mathrm{C}\right)\end{array}$ \\
\hline \multicolumn{8}{|c|}{ BR (Red Grape Balsamic Vinegars) } \\
\hline BR1 & Balsamic red & 2.7 & 19 & 8.6 & 0.77 & 154 & 126 \\
\hline BR2 & Balsamic red & 3.0 & 16 & 7.2 & 0.43 & 130 & 126 \\
\hline BR3 & Balsamic red & 3.1 & 14 & 7.4 & 0.92 & 114 & 118 \\
\hline BR4 & Balsamic red & 3.0 & 5.7 & 7.6 & 1.2 & 102 & 56 \\
\hline BR5 & Balsamic red & 3.1 & 27 & 6.9 & 0.74 & 197 & 135 \\
\hline BR6 & Balsamic red & 3.2 & 52 & 6.6 & 0.38 & 235 & 222 \\
\hline BR7 & Balsamic red & 2.8 & 7.7 & 7.8 & 0.38 & 113 & 68 \\
\hline BR8 & Balsamic red & 3.0 & 7.2 & 7.9 & 0.75 & 90 & 80 \\
\hline BR9 & Balsamic red & 3.2 & 15 & 7.1 & 0.32 & 162 & 96 \\
\hline BR10 & Balsamic red & 2.9 & 40 & 6.4 & 0.54 & 230 & 174 \\
\hline BR11 & Balsamic red bio & 3.0 & 50 & 6.8 & 0.26 & 278 & 178 \\
\hline BR12 & Balsamic red bio & 2.6 & 1.1 & 7.8 & 1.2 & 92 & 12 \\
\hline & mean $\pm \mathrm{SD}$ & $3.0 \pm 0.2$ & $21 \pm 17$ & $7.3 \pm 0.6$ & $0.66 \pm 0.33$ & $158 \pm 63$ & $116 \pm 58$ \\
\hline & median & 3.0 & 16 & 7.3 & 0.64 & 142 & 122 \\
\hline \multicolumn{8}{|c|}{ BRH (Red Grape Balsamic Vinegars with Honey) } \\
\hline BRH1 & Balsamic red honey & 2.9 & 27 & 7.8 & 1.1 & 189 & 144 \\
\hline BRH2 & Balsamic red honey & 3.2 & 9.1 & 7.8 & 0.27 & 151 & 60 \\
\hline BRH3 & Balsamic red honey & 3.2 & 14 & 7.2 & 0.40 & 211 & 66 \\
\hline BRH4 & Balsamic red honey & 2.9 & 12 & 7.2 & 0.32 & 273 & 44 \\
\hline BRH5 & Balsamic red honey & 3.3 & 13 & 6.7 & 0.44 & 197 & 68 \\
\hline & mean $\pm \mathrm{SD}$ & $3.1 \pm 0.2$ & $15 \pm 7$ & $7.4 \pm 0.6$ & $0.51 \pm 0.34$ & $204 \pm 44$ & $76 \pm 39$ \\
\hline & median & 3.2 & 13 & 7.2 & 0.40 & 197 & 66 \\
\hline \multicolumn{8}{|c|}{ BW (White Grape Balsamic Vinegars) } \\
\hline BW1 & Balsamic white & 2.9 & 23 & 7.0 & 0.17 & 145 & 161 \\
\hline BW2 & Balsamic white & 2.8 & 0.64 & 8.1 & 0.33 & 106 & 6.1 \\
\hline BW3 & Balsamic white & 2.8 & 0.94 & 8.0 & 0.08 & 128 & 7.3 \\
\hline & mean $\pm \mathrm{SD}$ & $2.8 \pm 0.1$ & $8.2 \pm 12.8$ & $7.7 \pm 0.6$ & $0.19 \pm 0.13$ & $126 \pm 20$ & $58 \pm 89$ \\
\hline & median & 2.8 & 0.94 & 8.0 & 0.17 & 128 & 7.3 \\
\hline \multicolumn{8}{|c|}{ WR (Wine Red Vinegars) } \\
\hline WR1 & Wine red & 2.8 & 3.3 & 7.8 & 0.16 & 32 & 102 \\
\hline WR2 & Wine red & 2.6 & 4.7 & 7.2 & 0.42 & 44 & 106 \\
\hline WR3 & Wine red & 2.6 & 1.1 & 7.3 & 1.3 & 30 & 36 \\
\hline WR4 & Wine red & 2.5 & 2.9 & 6.4 & 0.65 & 40 & 74 \\
\hline WR5 & Wine red & 2.4 & 0.29 & 7.3 & 0.08 & 28 & 10 \\
\hline WR6 & Wine red & 2.9 & 0.12 & 7.1 & 3.1 & 27 & 4.2 \\
\hline WR7 & Wine red & 2.7 & 0.24 & 7.5 & 0.47 & 41 & 5.8 \\
\hline WR8 & Wine red & 2.9 & 0.34 & 8.4 & 4.0 & 31 & 11 \\
\hline WR9 & Wine red & 3.4 & 2.2 & 7.6 & 0.16 & 30 & 73 \\
\hline WR10 & Wine red & 3.2 & 1.8 & 8.0 & 0.31 & 34 & 53 \\
\hline & mean $\pm \mathrm{SD}$ & $2.8 \pm 0.3$ & $1.7 \pm 1.6$ & $7.5 \pm 0.6$ & $1.1 \pm 1.4$ & $33.7 \pm 5.8$ & $48 \pm 40$ \\
\hline & medium & 2.8 & 1.4 & 7.4 & 0.44 & 31.6 & 45 \\
\hline \multicolumn{8}{|c|}{ WW (Wine White Vinegars) } \\
\hline WW1 & Wine white & 2.8 & 3.7 & 7.7 & 0.05 & 39 & 95 \\
\hline WW2 & Wine white & 2.6 & 0.09 & 7.2 & 0.31 & 30 & 3.0 \\
\hline WW3 & Wine white & 2.4 & 0.12 & 7.1 & 0.05 & 28 & 4.3 \\
\hline WW4 & Wine white & 2.5 & 0.40 & 7.2 & 2.7 & 28 & 14 \\
\hline WW5 & Wine white & 3.1 & 2.0 & 6.7 & $<0.01$ & 17 & 114 \\
\hline WW6 & Wine white & 3.2 & 0.86 & 8.5 & 0.06 & 26 & 33 \\
\hline WW7 & $\begin{array}{l}\text { Wine white with } \\
\text { rosemary and thyme }\end{array}$ & 2.9 & 1.2 & 7.1 & 0.61 & 34 & 36 \\
\hline WW8 & Champagne wine & 2.7 & 2.5 & 7.8 & 0.44 & 28 & 88 \\
\hline & mean $\pm S D$ & $2.8 \pm 0.3$ & $1.4 \pm 1.3$ & $7.4 \pm 0.6$ & $0.53 \pm 0.90$ & $28.8 \pm 6.3$ & $48 \pm 44$ \\
\hline & median & 2.7 & 1.0 & 7.2 & 0.18 & 28.1 & 34 \\
\hline \multicolumn{8}{|c|}{ F (Fruit Vinegars) } \\
\hline $\mathrm{F} 1$ & Apple & 2.8 & 3.7 & 7.9 & 0.06 & 34 & 21 \\
\hline $\mathrm{F} 2$ & Apple & 2.9 & 0.09 & 7.2 & 0.94 & 29 & 1.6 \\
\hline F3 & Apple & 3.8 & 0.12 & 7.0 & $<0.01$ & 19 & 113 \\
\hline $\mathrm{F} 4$ & Pomegranate & 2.2 & 0.40 & 7.4 & 0.70 & 19 & 28 \\
\hline F5 & Sea Buckthorn & 2.9 & 2.0 & 7.1 & 0.63 & 33 & 15 \\
\hline & mean $\pm S D$ & $2.9 \pm 0.6$ & $0.78 \pm 0.78$ & $7.3 \pm 0.4$ & $0.47 \pm 0.41$ & $26.7 \pm 7.4$ & $36 \pm 44$ \\
\hline & median & 2.9 & 0.54 & 7.2 & 0.63 & 29.1 & 21 \\
\hline
\end{tabular}


The $\mathrm{pH}$ showed a slightly higher fluctuation in common vinegars (2.2-3.8; median 2.8) compared to balsamic vinegars $(2.6-3.3 ; 3.0)$ (Table 1). Due to the acidity (low pH) of vinegars, the study of metal complexation becomes particularly interesting.

\subsection{Copper Complexation}

In environmental aqueous samples, copper toxicity is proportional to the concentration of inorganic $\left(\mathrm{Cu}^{2+}, \mathrm{Cu}^{0}\right)$ copper species, rather than the sum of all copper species comprising total dissolved copper concentration $[22,23]$. The quantification of organic copper complexation has become increasingly important in natural waters and other natural systems since organic ligands effectively buffer the system against small changes in dissolved copper concentrations and are able to maintain the free $\mathrm{Cu}^{2+}$ concentration below the toxicity threshold [22]. In aqueous environmental settings dissolved organic carbon (DOC) occurs as a spectrum of different species, many of which may not have a specific chemical formula [24]. As such, the metal-binding capacity of different DOC fractions is highly variable and significant for environmental samples.

The $L_{\mathrm{T}}$ concentrations measured in vinegars are characterized by a significant variation among the different samples examined, with their values ranging from $0.05 \mu \mathrm{M}$ in sample $\mathrm{F} 2$ to $52 \mu \mathrm{M}$ in sample BR6 (Figure 1; Table 1). Balsamic vinegars demonstrated a considerably higher median $L_{\mathrm{T}}$ value (14 $\mu \mathrm{M})$ compared to common vinegars $(0.86 \mu \mathrm{M})$ (Mann-Whitney test, $p<0.001)$, with the highest median concentrations obtained for red grape balsamic vinegars $(16 \mu \mathrm{M})$, followed by red grape balsamic vinegars with honey $(13 \mu \mathrm{M})$ (Table 1$)$. The lowest median $L_{\mathrm{T}}$ concentration was measured in fruit vinegars $(0.54 \mu \mathrm{M})$.

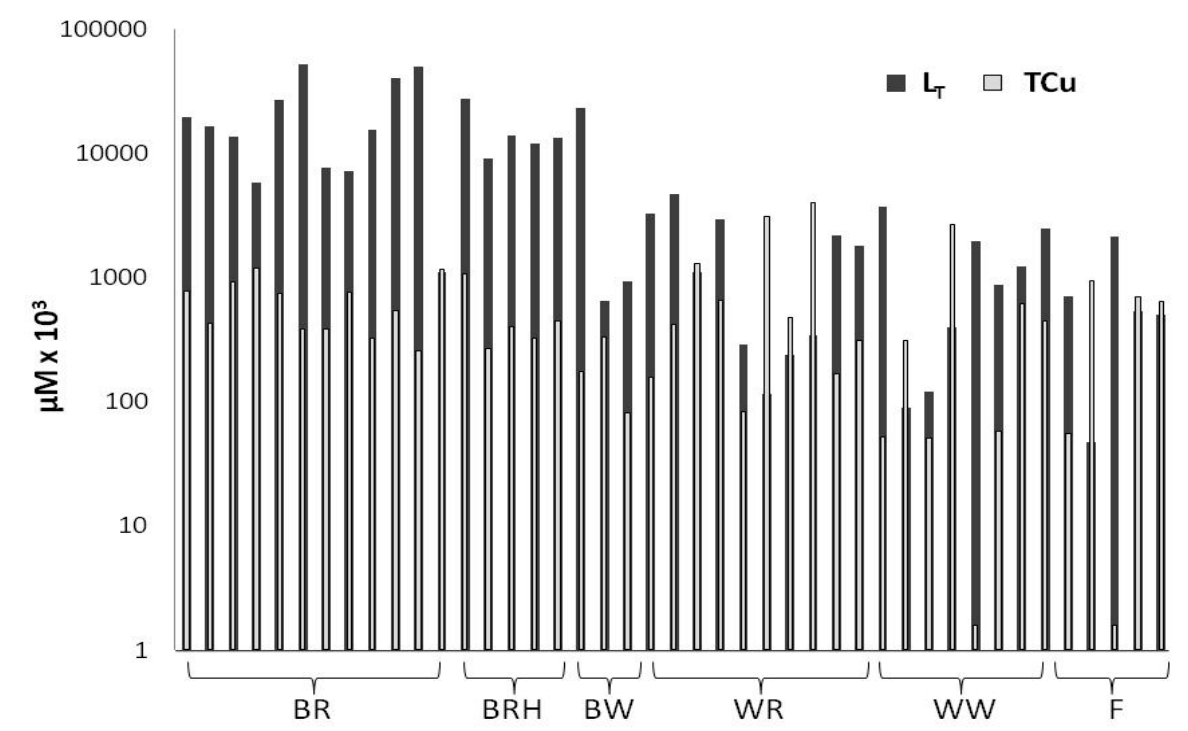

Figure 1. $L_{\mathrm{T}}$ and TCu concentrations (logarithmic scale) in vinegars (BR: balsamic red vinegar, $n=12$; BRH: balsamic red vinegar with honey, $n=5$; BW: balsamic white vinegar, $n=3$; WR: wine red vinegar, $n=10$; WW: wine white vinegar, $n=8$; F: fruit vinegar, $n=5$ ).

The values of $\log K_{a p p}$, expressing the stability of $\mathrm{Cu}$-ligand complexes, ranged from 6.4 to 8.6 (Table 1). The identical median $\log K_{a p p}$ values calculated herein for both balsamic (7.3) and common vinegars (7.3) ( $p>0.05$; Table 1) indicate the presence of ligands likely sharing similar chemical characteristics, despite the variation characterizing $\log K_{a p p}$ values among the samples analyzed. A slightly higher median $\log K_{a p p}$ value obtained for white grape balsamic vinegars (8.0) indicates the presence of rather different $\mathrm{Cu}$ ligands in the specific category.

Total $\mathrm{Cu}$ concentrations also varied significantly among the samples examined, ranging from $<0.01$ to $4.0 \mu \mathrm{M}$ (Figure 2, Table 1), with $30 \%$ of white grape balsamic vinegars having total $\mathrm{Cu}$ concentrations exceeding $1.0 \mu \mathrm{M}$. 

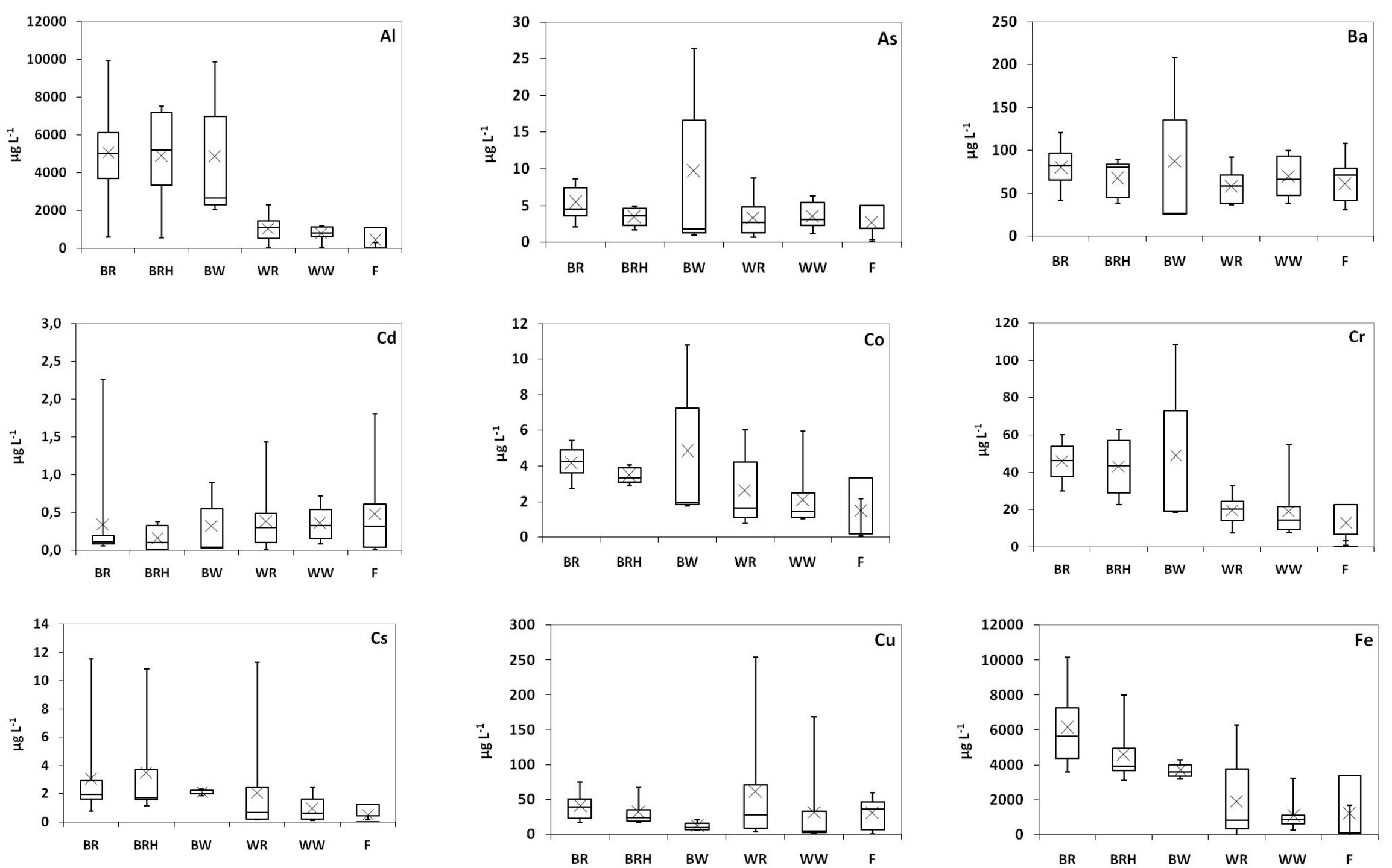

Figure 2. Cont. 

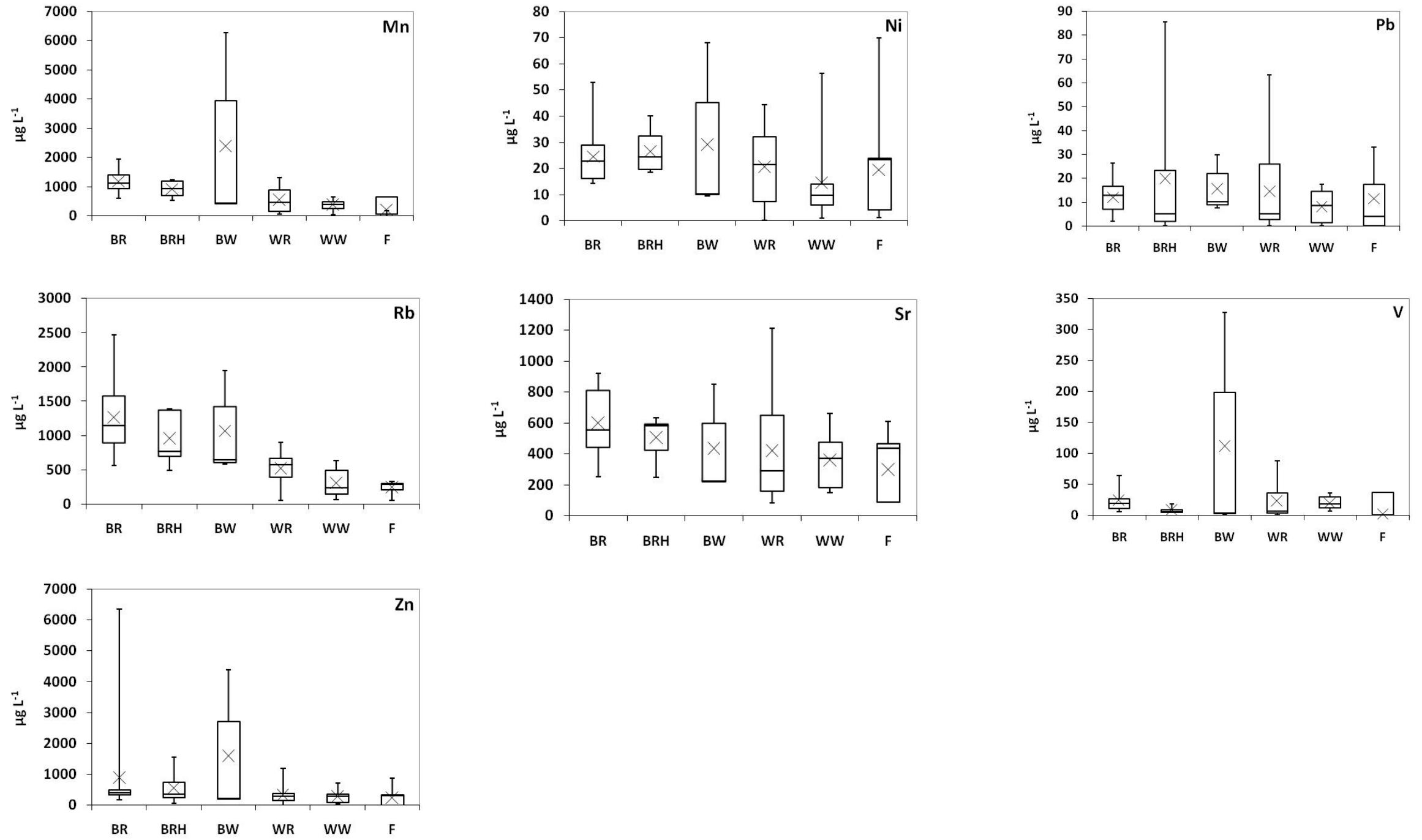

Figure 2. Plots of trace metals determined for all vinegar samples examined. The mean value is displayed with $\mathrm{x}$. (BR: balsamic red vinegar; BRH: balsamic red vinegar with honey; BW: balsamic white vinegar; WR: wine red vinegar; WW: wine white vinegar; F: fruit vinegar). 
In $21 \%$ of the vinegar samples analyzed, $L_{\mathrm{T}}$ values were exceeded by total $\mathrm{Cu}$ concentrations, indicating the presence of labile $\mathrm{Cu}$, either free or bound in weak complexes (Figure 1). This may be attributed to the high acidity of vinegar samples, with their pH lying between 2.2 and 3.8 (Table 1), and/or to their high $\mathrm{Cu}$ content. Almost $90 \%$ of the samples in which the presence of labile Cu was recorded were common vinegars, which are characterized by the lowest organic carbon concentrations. In common vinegars, high acidity combined with relatively low organic carbon concentrations seem to favor the presence of free/labile $\mathrm{Cu}$ ions.

The present results are considerably different from those obtained so far for samples of Greek herbal infusions [25], coffee brews [26], and Greek beers [27] in which the contained Cu was found to be fully complexed. It is quite peculiar that samples with such low $\mathrm{pH}$ values like vinegars exhibit $L_{\mathrm{T}}$, as it is known that the lower the $\mathrm{pH}$ of the sample, the lower the $L_{\mathrm{T}}$, since binding sites become protonated at lower $\mathrm{pH}$ levels and less prone to forming complexes. However, in the case of vinegars, it is obvious that compounds such as melanoidins (precursors of humic material), Maillard reaction endproducts, and phenolic compounds exist, capable of forming stable $\mathrm{Cu}$ complexes even at lower pHs. Similar features (i.e., high $\mathrm{Cu}$ complexing capacity) were observed for swamp water samples (Okefenokee swamps, Georgia, GA, USA) with a high content of humic material (even the color of the samples was light brown) and $\mathrm{pH}$ of 2.7 with $L_{\mathrm{T}}$ of $0.46 \mu \mathrm{M}$ measured during the 1980s (personal communication with Dr. Marta Plavšić).

A Kruskal-Wallis $\mathrm{H}$ nonparametric test showed that there was a statistically significant difference in the median values of $L_{\mathrm{T}}(p<0.001)$ and OC concentrations $(p<0.001)$, among the six subgroups into which the vinegar samples were classified. The aforementioned test also demonstrated that the differences in the median values among the different vinegar groups regarding $\mathrm{pH}(p=0.152), \mathrm{Cu}$ concentrations $(p=0.244)$, and $\log K_{a p p}$ values $(p=0.891)$ were not statistically significant. It seems that $L_{\mathrm{T}}$ concentrations are related to the amount of organic matter present (Figure 3A1), whereas parameters such as acidity (Figure 3B1,B2) and nature of $\mathrm{Cu}$ ions ligands do not differentiate significantly among the vinegar categories examined.

A1

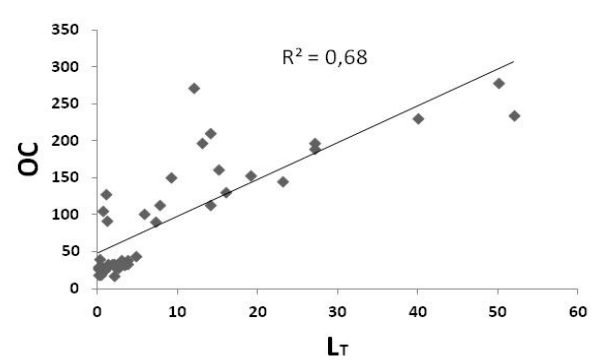

A2

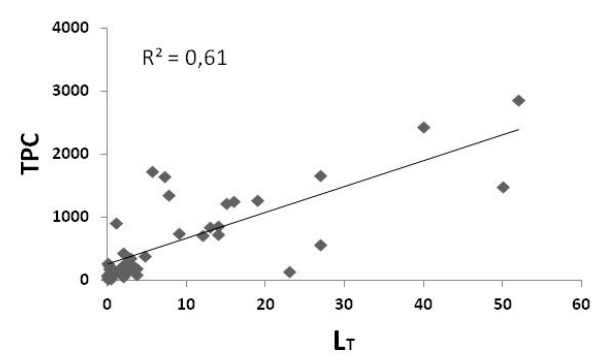

B1

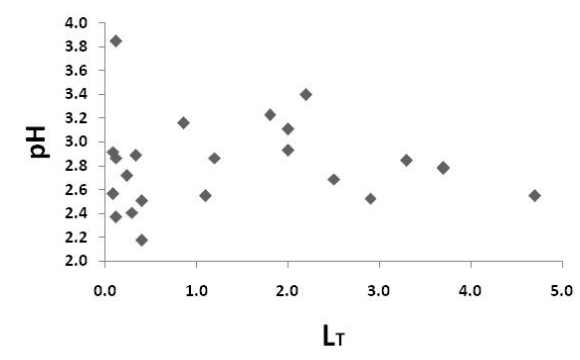

B2

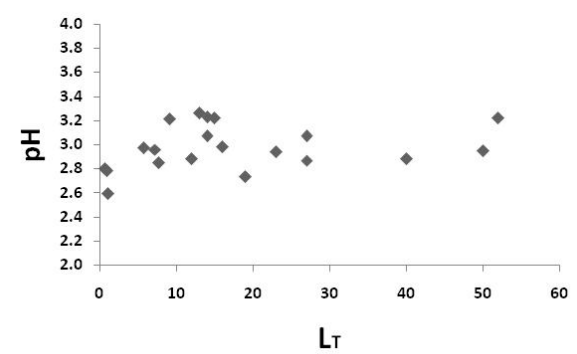

Figure 3. Correlation of $L_{\mathrm{T}}(\mu \mathrm{M})$ with organic carbon $(\mathrm{OC})\left(\mathrm{mg} \mathrm{L}^{-1}\right)(\mathbf{A 1})$ and total phenolics (TPC) (mg GAE L ${ }^{-1}$ ) concentrations (A2) and correlation of $L_{\mathrm{T}}$ with $\mathrm{pH}$ values in common (B1) and balsamic vinegars (B2). 
Due to differences characterizing the organic matter content of vinegar samples, the normalization of $L_{\mathrm{T}}$ values in terms of organic carbon concentration provides information on the amount of $\mathrm{Cu}$ ligands per organic carbon mass unit. The density of $\mathrm{Cu}$ ligands per mass unit of organic matter (nmol $\mathrm{Cu} \mathrm{mg}{ }^{-1} \mathrm{C}$ ) was found higher in balsamic vinegars originating from red grapes (median concentration $122 \mathrm{nmol} \mathrm{Cu} \mathrm{mg}{ }^{-1} \mathrm{C}$ in BR, $76 \mathrm{nmol} \mathrm{Cu} \mathrm{mg}{ }^{-1} \mathrm{C}$ in BRH), compared to those calculated for the rest of the samples examined ( $45 \mathrm{nmol} \mathrm{Cu} \mathrm{mg}{ }^{-1} \mathrm{C}$ in CR, 34 in CW, 21 in CF, 7.3 in BW) (Table 1). These values obtained for red grape balsamic vinegars are also higher compared to those of Greek herbal infusions, reaching $128 \mathrm{nmol} \mathrm{Cu} \mathrm{mg}{ }^{-1} \mathrm{C}$, coffee brews (31-59 nmol Cu mg${ }^{-1} \mathrm{C}$ ) and Greek beers (0.91-7.0 nmol $\mathrm{Cu} \mathrm{mg}^{-1} \mathrm{C}$ ) (Table S1; Supplemental Material). This comparison is feasible since in all aforementioned cases, $L_{\mathrm{T}}$ concentrations were determined by the same analytical method (DPASV), having the same "detection window".

Copper complexes have revealed a significant performance in antioxidant studies [28], something confirmed by the positive correlation of $L_{\mathrm{T}}$ values with the total phenolic content (TPC; data in Sinanoglou et al. [29]) of vinegar samples $\left(\mathrm{R}^{2}=0.61, p<0.05\right)$ (Figure 3A2). Alonso et al. [30] have shown that in wine and other grape-derived products, a positive correlation can be established between the antioxidant activity and total phenolic content of samples, albeit not with specific compounds. Similarly, in vinegars, despite the correlation of complexing capacity of $\mathrm{Cu}$ ions with the total phenolic content of the samples, no corresponding correlations with specific categories of phenolic compounds (e.g., phenolic alcohols, phenolic acids, phenolic aldehyde; data in Sinanoglou et al. [29]) were observed.

The higher enrichment of the organic matter of red grape balsamic vinegars in $\mathrm{Cu}$ ligands is related with their production process. Contrary to white grape balsamic vinegars, the specific vinegars have undergone concentration and for their production, grape skins and seeds have been used. Similarly to red wine vinegars, red grape balsamic vinegars are expected to contain phenolic substances at levels even 10-fold higher than balsamic vinegars from white grapes. Polyphenols are the main phenolic compounds extracted from grapes during the winemaking process, initially obtained by fruit crushing and intensified through maceration and pumping-over processes carried out during fermentation [31]. Proanthocyanidins (condensed tannins) are among the most widespread polyphenol species in plants, often accumulating at large quantities in leaves, fruits, wood, or bark [32]. Most tannin molecules contain o-dihydroxyphenyl chelating functional groups, forming stable complexes with many metal ions $[33,34]$.

\subsection{Trace Elements}

Sixteen trace elements, namely $\mathrm{Al}$, As, $\mathrm{Ba}, \mathrm{Cd}, \mathrm{Co}, \mathrm{Cr}, \mathrm{Cs}, \mathrm{Cu}, \mathrm{Fe}, \mathrm{Mn}, \mathrm{Ni}, \mathrm{Pb}, \mathrm{Rb}, \mathrm{Sr}, \mathrm{V}$, and Zn, were determined in the examined vinegar samples (Figure 2; Table S2). Median concentrations $>1000$ $\mu \mathrm{g} \mathrm{L}{ }^{-1}$ were determined for Fe and Al, between 10 and $1000 \mu \mathrm{g} \mathrm{L}{ }^{-1}$ for $\mathrm{Rb}, \mathrm{Mn}, \mathrm{Sr}$ and $\mathrm{Zn}$, between 10 and $100 \mu \mathrm{g} \mathrm{L}^{-1}$ for $\mathrm{Cu}, \mathrm{Cr}, \mathrm{Ni}$, and $\mathrm{V}$, and $<10 \mu \mathrm{g} \mathrm{L}^{-1}$ for $\mathrm{Pb}, \mathrm{As}, \mathrm{Co}, \mathrm{Cs}$, and Cd. Arsenic, lead, and cadmium are particularly important environmental and industrial pollutants, currently ranked first, second, and seventh, respectively, in the 2017 Priority List of Hazardous Substances of the US Agency for Toxic Substances and Diseases Registry (http://www.atsdr.cdc.gov/SPL/), on the basis of their easy accessibility, toxicity, and potential for human exposure.

Arsenic concentrations in individual vinegar samples ranged from $<0.05 \mu \mathrm{g} \mathrm{L}^{-1}$ in a fruit vinegar (apple) to $26 \mu \mathrm{g} \mathrm{L}^{-1}$ in a balsamic vinegar from white grapes, with median concentrations calculated equal to 2.6 and $4.2 \mu \mathrm{g} \mathrm{L}{ }^{-1}$ in common and balsamic vinegars, respectively (Figure 2), without the difference being statistically significant (Mann-Whitney test; $p=0.095)$. In order to calculate the arsenic intake through the consumption of the studied vinegars, the PTDI (provisional tolerable daily intake) for As (126 $\mu \mathrm{g}$ per day for a $60 \mathrm{~kg}$ person) was withdrawn, since the BMRL0.5 value (lower limit on the benchmark dose for a $0.5 \%$ response) has been calculated at the same range, e.g., $180 \mu \mathrm{g}$ per day (for a $60 \mathrm{~kg}$ person) as being responsible for causing lung cancer [35]. Considering a daily vinegar consumption equal to one tablespoon $(15 \mathrm{~mL})$, the maximum As daily intake from the studied vinegar 
was calculated to be equal to $0.40 \mu \mathrm{g}$, being significantly lower-almost up to 300 times-than the withdrawn PTDI limit.

The range of $\mathrm{Pb}$ concentrations measured herein extends from $<0.05 \mu \mathrm{g} \mathrm{L} \mathrm{L}^{-1}$ in both an individual balsamic vinegar with fruits and several common vinegars to $86 \mu \mathrm{g} \mathrm{L}^{-1}$ in a balsamic red vinegar with honey. The second highest concentration $\left(63 \mu \mathrm{g} \mathrm{L}^{-1}\right)$ was detected in a balsamic sample from red grapes. The corresponding median $\mathrm{Pb}$ concentrations in common and balsamic vinegars were calculated at 6.0 and $9.8 \mu \mathrm{g} \mathrm{L}{ }^{-1}$, respectively, without a statistically significant difference $(p=0.654)$. California State's maximum level of $\mathrm{Pb}$ for human consumption $(0.5 \mu \mathrm{g} \mathrm{Pb}$ per day), corresponding to $\mathrm{Pb}$ concentrations equal or higher than $34 \mu \mathrm{g} \mathrm{L}^{-1}$ [6], was exceeded in only 2 vinegar samples, representing $5 \%$ of those examined.

Cadmium concentrations ranged from $0.03 \mu \mathrm{g} \mathrm{L}{ }^{-1}$ in both individual balsamic vinegars from red grapes with honey and common vinegars from red grapes and fruits (apple) to $2.3 \mu \mathrm{g} \mathrm{L}^{-1}$ in an aged balsamic vinegar from red grapes. Significant $\mathrm{Cd}$ concentrations were determined in common vinegars with fruits (apple) $\left(1.8 \mu \mathrm{g} \mathrm{L}^{-1}\right)$ and vinegars from red grapes $\left(1.4 \mu \mathrm{g} \mathrm{L}^{-1}\right)$. The median $\mathrm{Cd}$ concentration was higher in common $\left(0.30 \mu \mathrm{g} \mathrm{L}^{-1}\right)$ in comparison to balsamic vinegars $\left(0.10 \mu \mathrm{g} \mathrm{L}^{-1}\right)$ $(p=0.046)$. In any case, $\mathrm{Cd}$ concentrations determined in vinegar samples were significantly lower than the recommended PTDI (50 $\mu \mathrm{g}$ per day for a $60 \mathrm{~kg}$ person) [36], corresponding to a $3.3 \mathrm{mg}$ $\mathrm{L}^{-1}$ concentration.

For the rest of trace elements examined, higher concentrations in balsamic compared to common vinegars were obtained for $\mathrm{Al}$ (median concentration $4657 \mu \mathrm{g} \mathrm{L}^{-1}$ in balsamic, $768 \mu \mathrm{g} \mathrm{L}^{-1}$ in common vinegar, $p<0.001)$, Cr (44 vs. $\left.17 \mu \mathrm{g} \mathrm{L}^{-1}, p<0.001\right)$, Fe (4394 vs. $\left.782 \mu \mathrm{g} \mathrm{L}^{-1}, p<0.001\right)$, Mn (1055 vs. $\left.357 \mu \mathrm{g} \mathrm{L}^{-1}, p<0.001\right), \mathrm{Rb}\left(1053\right.$ vs. $\left.318 \mu \mathrm{g} \mathrm{L}^{-1}, p<0.001\right)$, Co (4.0 vs. $\left.1.4 \mu \mathrm{g} \mathrm{L}^{-1}, p=0.004\right)$, $\mathrm{Sr}(555 \mathrm{vs}$. $\left.329 \mu \mathrm{g} \mathrm{L}{ }^{-1}, p=0.004\right)$, and Cs (1.9 vs. $\left.0.60 \mu \mathrm{g} \mathrm{L}-1, p=0.004\right)$. No statistically significant differences in median concentrations were observed between the two vinegar categories regarding $\mathrm{Ba}, \mathrm{Cu}, \mathrm{V}, \mathrm{Ni}$, and $\mathrm{Zn}(p>0.05)$.

In order to evaluate any data trends and gain an overview of the relationships among the trace metals examined, principal component analysis (PCA) was performed individually for common and balsamic vinegar samples. In each factor analysis, metals which do not relate satisfactorily with the rest of the trace metals studied (measure sampling adequacy (MSA) values $<0.5$ ) were excluded. For the remaining ones, the value of the Kaiser-Meyer-Olkin (KMO) statistical criterion is equal to 0.86 and 0.85 for common and balsamic vinegars, respectively, and factor analysis is feasible. Two principal components (PCs) with eigenvalues $>1$ were extracted (PC1 explained up to $77 \%$ and $81 \%$ of the total variance for common and balsamic vinegars and PC2 explained up to $9 \%$ and $10 \%$, respectively). In common vinegars, a statistically acceptable factor analysis is feasible for $\mathrm{Al}, \mathrm{Co}, \mathrm{Fe}, \mathrm{Mn}, \mathrm{Ni}$, and $\mathrm{Sr}$, whereas in balsamic vinegars, for $\mathrm{As}, \mathrm{Ba}, \mathrm{Co}, \mathrm{Mn}, \mathrm{V}$, and $\mathrm{Zn}$. According to the component plot obtained for balsamic vinegars (Figure S1), As, Ba, Co, Mn, and V are clustered well, whereas $\mathrm{Zn}$ appears to differentiate. Apparently, natural soil components constitute the main source of $\mathrm{As}, \mathrm{Ba}, \mathrm{Co}, \mathrm{Mn}$, and $\mathrm{V}$, since the concentrations of trace metals such as $\mathrm{As}, \mathrm{Ba}, \mathrm{Co}$, and $\mathrm{V}$ are not expected to be affected by processing and storage processes. Considering $\mathrm{Zn}$, the anthropogenic impact, such as from the use of fertilizers, appears to be significant. It is noteworthy that in common vinegars, the clusters in PCA analysis (Figure S1) are more scattered compared to those in balsamic vinegars, demonstrating weaker relationships among the trace metals examined. In common vinegars in which neither the raw material quality nor the technological producing procedures are controlled as effectively as in balsamic vinegars, there are multiple sources of trace metals which are not common to all samples. No satisfactory discrimination was achieved for the two vinegar categories by the factor analysis score plots of trace metals.

In order to obtain additional information on metal concentration levels and their potential magnification in vinegars, indicative enrichment factors (IEFs) were calculated for individual elements in terms of the average elemental composition of the upper continental crust, since the main raw materials in vinegar production are grape juice and/or wine, where the trace metals that enter originate 
from the soil during vine growth. The enrichment factors calculated herein are only indicative, since metals differ in their reactivity and this influences their availability for uptake from the soil by plants (e.g., vineyards) and transfer into the food chain [37,38]. For each one of the examined trace metals, Fe was used as the reference element considering the upper continental crustal composition given by Rudnick and Gao [39]. The indicative enrichment factor (IEF) of an element $E$ is defined according to Equation (1):

$$
\mathrm{IEF}=(\mathrm{E} / \mathrm{R})_{\text {vinegar }} /(\mathrm{E} / \mathrm{R})_{\text {crust }},
$$

where $\mathrm{E}$ and $\mathrm{R}$ represent the concentrations of examined and reference element, respectively. Operationally, if IEF approaches 1, no significant alteration of the examined element from the relative composition of the earth's crust exists, whereas high IEFs indicate significant alteration from local variation in soil composition and possible magnification in vinegar samples. IEF values close to 100 were determined for $\mathrm{Rb}, \mathrm{Zn}$, and $\mathrm{Cd}$; close to 50 for $\mathrm{As}$; and between 10 and 25 for $\mathrm{Cu}, \mathrm{Mn}, \mathrm{Pb}$, and Cs; whereas for the rest of the trace elements studied, Efs $<10$ were calculated. $\mathrm{Zn}, \mathrm{Cu}$, and $\mathrm{Mn}$ are present as necessary trace elements in fertilizers $[40,41]$ that are applied in viniculture. Copper, either alone or combined with sulfur, is extensively applied as a pesticide in vineyards [42]. Both $\mathrm{Cd}$ and $\mathrm{Rb}$ are present in phosphate fertilizers, originating from parent raw materials [43,44]. Cultivation practices applied in viniculture, such as the use of fertilizers and plant protection products, potentially contribute to the trace metal content of vinegars, for which significant IEFs were calculated, albeit that it was not possible to evaluate the contribution from the use of either tools or storage media. Despite the relatively high IEFs obtained for $\mathrm{Zn}$, its concentrations measured in vinegar samples were significantly lower compared to the recommended PMTDI (provisional maximum tolerable daily intake) (18-60 mg per day for a $60 \mathrm{~kg}$ person) [45], corresponding to a concentration ranging from 1200 to $4000 \mathrm{mg}$ $\mathrm{L}^{-1}$. Regarding $\mathrm{Rb}$, for which high IEFs were also obtained, it demonstrates transport mechanisms in plant roots similar to those of $\mathrm{K}$, which constitutes an essential element for plants [46]. Recently, at a coastal area of Israel in eastern Mediterranean Sea, elevated $\mathrm{Rb}$ concentrations were reported in soils, soil solutions, rainwater through fall water and plant litter leachates, with sea aerosols constituting a major input [47]. Similarly, Campbell et al. [48] proposed that Rb should be included as a metal that is consistently biomagnified in diverse food webs and should hence be considered in multi-element biomagnification studies.

Table 2 shows a comparison of the concentrations of trace metals examined in the present study with those reported in literature for vinegars produced and/or retailed in different places. Trace metals levels lying in the lower range of the concentrations reported in literature were determined in the present work. A high variation characterizes the concentrations of specific metals such as $\mathrm{Cd}$, $\mathrm{Cr}, \mathrm{Cu}, \mathrm{Fe}, \mathrm{Ni}, \mathrm{Pb}$, and $\mathrm{Zn}$ reported in the different studies, possibly due to a contamination of the raw material and/or to technological manipulations constituting potential sources of these metals in vinegars, with the latter appearing to be more important. Similarly, Ndung'u et al. [6], studying the $\mathrm{Pb}$ isotopic fingerprints in vinegars, reported that the main $\mathrm{Pb}$ sources are anthropogenic, with chemicals added during production and/or material used during transport, processing, or storage being significant. Table vinegars typically contain no less than $4 \%$ per weight acetic acid, which undergoes the typical chemical reactions of carboxylic acids, being corrosive against mild steel and accelerating the dissociation of metals, including $\mathrm{Fe}, \mathrm{Mg}$, and $\mathrm{Zn}$ [17]. 
Table 2. Concentrations of trace metals in different types of vinegars reported in literature. Countries refer to place of retail.

\begin{tabular}{|c|c|c|c|c|c|c|c|c|c|c|c|c|c|c|}
\hline & $\mathrm{Al}\left(\mathrm{mg} \mathrm{L}^{-1}\right)$ & $\begin{array}{c}\text { As } \\
\left(\mu \mathrm{g} \mathrm{L}^{-1}\right)\end{array}$ & $\begin{array}{c}\text { Ba } \\
\left(\mu \mathrm{g} \mathrm{L}^{-1}\right)\end{array}$ & $\begin{array}{c}\mathrm{Cd} \\
\left(\mu \mathrm{g} \mathrm{L}^{-1}\right)\end{array}$ & $\begin{array}{c}\text { Co } \\
\left(\mu \mathrm{g} \mathrm{L}^{-1}\right)\end{array}$ & $\begin{array}{c}\mathrm{Cr} \\
\left(\mu \mathrm{g} \mathrm{L}^{-1}\right)\end{array}$ & $\begin{array}{c}\mathrm{Cu} \\
\left(\mu \mathrm{g} \mathrm{L}^{-1}\right)\end{array}$ & $\begin{array}{c}\mathrm{Fe} \\
\left(\mathrm{mg} \mathrm{L}^{-1}\right)\end{array}$ & $\begin{array}{c}\mathrm{Mn} \\
\left(\mathrm{mg} \mathrm{L}^{-1}\right)\end{array}$ & $\begin{array}{c}\mathrm{Ni} \\
\left(\mu \mathrm{g} \mathrm{L}^{-1}\right)\end{array}$ & $\begin{array}{c}\mathrm{Pb} \\
\left(\mu \mathrm{g} \mathrm{L}^{-1}\right)\end{array}$ & $\begin{array}{c}\mathrm{Sr} \\
\left(\mathrm{mg} \mathrm{L}^{-1}\right)\end{array}$ & $\begin{array}{c}\mathrm{V} \\
\left(\mu \mathrm{g} \mathrm{L}^{-1}\right)\end{array}$ & $\begin{array}{c}\mathrm{Zn} \\
\left(\mathrm{mg} \mathrm{L}^{-1}\right)\end{array}$ \\
\hline \multicolumn{15}{|l|}{ Wine vinegars } \\
\hline Spain [3] & $0.85-7.11$ & $<20$ & $40-164$ & $<1$ & $3-77$ & $17-2090$ & $17-8580$ & $1.18-19.0$ & $0.049-1.66$ & $2-903$ & $35-2200$ & $0.196-1.83$ & $11-147$ & $0.040-6.12$ \\
\hline Spain [49] & & n.d. -23 & & & & & $20-6170$ & $1.24-75.8$ & $0.15-5.44$ & & & & & $0.06-8.56$ \\
\hline Spain [50] & & & & & & & $320 \pm 130$ & & & & & & & $0.72 \pm 0.11$ \\
\hline Spain [51] & & 136 & & & & & $1350 \pm 40$ & $8.44 \pm 0.07$ & & & $550 \pm 50$ & & & $7.86 \pm 0.51$ \\
\hline Brazil [20] & $0.12-2.98$ & & $20-400$ & & & & $10-50$ & & $0.04-10.0$ & & & & & $<0.01-2.0$ \\
\hline Brazil [52] & & & & $0.02-0.89$ & & & & & & & & & & \\
\hline Canary islands $[53,54]$ & & & & $12-245$ & & & $1440 \pm 380$ & $2.08 \pm 1.09$ & & $48-205$ & $360-1280$ & & & $1.63 \pm 0.28$ \\
\hline Turkey [55] & & & & & & & $130 \pm 19$ & $4.25 \pm 1.95$ & $0.78 \pm 0.43$ & $50 \pm 27$ & $20 \pm 24$ & & & $0.10 \pm 0.019$ \\
\hline Turkey [56] & $0.55-3.07$ & & & & n.d. -620 & 2950-3950 & $10-130$ & $0.38-5.12$ & $0.05-2.49$ & & $10-150$ & & & $0.16-2.07$ \\
\hline Iran [57] & & & & n.d. -59.3 & & & $12.8-584$ & & & & $3.32-167$ & & & $0.03-1.9$ \\
\hline California, USA [19] & & & & & & & & & & & $36-50$ & & & \\
\hline California, USA [6] & & & & & & & & & & & $7.4-590$ & & & \\
\hline Greece * & $<0.002-2.3$ & $0.66-8.7$ & $37-100$ & $<0.030-1.4$ & $0.78-6.0$ & $7.5-55$ & $<0.40-254$ & $<0.003-6.3$ & $0.04-1.3$ & $<0.40-56$ & $<0.050-63$ & $0.08-1.2$ & $0.31-88$ & $0.01-1.2$ \\
\hline \multicolumn{15}{|l|}{ Balsamic vinegars } \\
\hline Turkey [55] & & & & $20 \pm 5$ & & & $420 \pm 153$ & $6.94 \pm 1.50$ & $1.31 \pm 0.18$ & $30 \pm 19$ & $20 \pm 25$ & & & $0.36 \pm 0.162$ \\
\hline Turkey [56] & $0.56-2.29$ & & & & n.d. 260 & 1980-2090 & $10-30$ & $2.51-7.01$ & $0.02-0.14$ & & 10 & & & $0.26-0.79$ \\
\hline California, USA [19] & & & & & & & & & & & $15-307$ & & & \\
\hline California, USA [6] & & & & & & & & & & & $14-720$ & & & \\
\hline Greece * & $0.56-10$ & $0.93-26$ & $27-208$ & $<0.030-2.3$ & $1.8-11$ & 19-109 & $5.2-75$ & $3.1-10$ & $0.43-6.3$ & $9.6-68$ & $<0.050-86$ & $0.23-0.92$ & $1.9-328$ & $0.06-6.4$ \\
\hline \multicolumn{15}{|l|}{ Fruit vinegars } \\
\hline CanaryIslands [52,53] & & & & $12-37$ & & & $570 \pm 140$ & $1.14 \pm 0.45$ & & $48-201$ & $350-550$ & & & $0.25 \pm 0.04$ \\
\hline Turkey [55] & & & & $10 \pm 4$ & & & $30 \pm 32$ & $1.31 \pm 0.58$ & $0.18 \pm 0.13$ & $10 \pm 13$ & $10 \pm 8$ & & & \\
\hline Turkey [56] & $0.32-5.19$ & & & & & $1970-2330$ & $10-50$ & $0.27-6.84$ & $0.03-1.51$ & & $10-80$ & & & $0.29-2.42$ \\
\hline Iran [57] & & & & n.d. -78 & & & $32-1129$ & & & & $4.4-253$ & & & $0.05-3.7$ \\
\hline California, USA [6] & & & & & & & & & & & $3.7-7.4$ & & & \\
\hline Greece* & $<0.002-1.4$ & $<0.050-5.4$ & $31-108$ & $<0.030-1.8$ & $0.08-5.5$ & $0.88-26$ & $<0.40-60$ & $<0.003-5.1$ & $<0.01-0.83$ & $1.3-70$ & $<0.050-33$ & $0.09-0.61$ & $<0.050-6.2$ & $<0.01-0.88$ \\
\hline
\end{tabular}

* Present study 


\section{Materials and Methods}

\subsection{Sampling}

Forty-three (twenty-three common and twenty balsamic) vinegars were purchased from different producers (Table 1). The vinegar samples were furthermore categorized in vinegars produced from red $(\mathrm{WR} ; n=10)$ and white wine (WW; $n=8)$, fruit vinegars $(\mathrm{F} ; n=3)$, balsamic vinegars from red grapes (BR; $n=12)$, balsamic vinegars from red grapes with honey $(\mathrm{BRH} ; n=5)$, and balsamic vinegars from white grapes (BW; $n=3)$ (Table 1$)$.

\subsection{Electrochemical Measurements}

\subsubsection{Sample Preparation and Equipment}

For the determination of $L_{\mathrm{T}}, 5 \mathrm{~mL}$ of vinegar samples were 10-fold diluted with Milli-Q water, 18.2 $\mathrm{M} \Omega \mathrm{cm}$ (Millipore, Bedford, MA, USA). Following addition of 5 drops of $3 \mathrm{M} \mathrm{NaCl}$, samples were immediately subjected to copper complexing capacity $\left(L_{\mathrm{T}}\right)$ and apparent stability constant $\left(K_{\text {app }}\right)$ determinations.

Electrochemical measurements were carried out using a $\mu$ Autolab type III (Eco-Chemie, Utrecht, The Netherlands) instrument connected to a three-electrode cell (663 VA Stand, Metrohm, Herisau, Switzerland) with a static mercury drop electrode (SMDE) as the working electrode. The reference electrode was an $\mathrm{Ag} / \mathrm{AgCl}(3 \mathrm{M} \mathrm{KCl})$. A carbon rod electrode served as the auxiliary electrode.

\subsubsection{Copper Complexing Capacity $\left(L_{\mathrm{T}}\right)$}

Differential pulse anodic stripping voltammetry (DPASV) was used for complexing capacity determinations [15]. The imposed experimental conditions on the electrode system were modulation time $0.04 \mathrm{~s}$, interval time $0.31 \mathrm{~s}$, modulation amplitude $25 \mathrm{mV}$, and step potential $5 \mathrm{mV}$. The measurements were performed by direct titrations of the samples, to which the supporting electrolyte $(\mathrm{NaCl})$ was added in the voltammetric cell with the standard addition of copper ions. The equilibration time of $15 \mathrm{~min}$ between the addition of copper ion and the measurement was proven adequate for attaining equilibrium in the sample. During the accumulation period in the cell a potential of $-0.6 \mathrm{~V} v \mathrm{vg} . \mathrm{Ag} / \mathrm{AgCl}$ reference electrode was applied, and copper ions were reduced on the electrode in the form of amalgam. In the oxidation step (stripping step) which follows, copper is oxidized from the amalgam, giving rise to a voltammetric peak, the height (current) of which is then used for the calculation of $L_{\mathrm{T}}$. The sensitivity of the method and the total amount of copper ions present were determined in the same way in the acidified ( $\mathrm{pH}=2$ ) sample solution, using a standard additions titration procedure.

When all ligands capable of complexing copper ions in the sample are saturated with the added copper ions, the slopes of the titration lines at natural $\mathrm{pH}$ and acidified samples become parallel and the approximate $L_{\mathrm{T}}$ value is calculated by extrapolation of these titration lines to the $x$-axis. Exact values of copper complexing capacity $\left(L_{\mathrm{T}}\right)$ as well as of corresponding apparent stability constants $\left(K_{\text {app }}\right)$ were calculated by applying the linear transformation plot through linearly transforming titration data, assuming 1:1 metal to ligand complexation [58,59]. The equation used for calculation is [Cu]/[CuL] $=[\mathrm{Cu}] / L_{\mathrm{T}}+1 / K L_{\mathrm{T}}$, where $\mathrm{Cu}$ is the copper ion detected by anodic stripping voltammetry, $\mathrm{CuL}$ is the copper ion bound in a complex with ligand $\mathrm{L}, L_{\mathrm{T}}$ is the total concentration of binding ligands (complexing capacity), and $K$ is the apparent stability constant. The plot of $[\mathrm{Cu}] /\left[L_{\mathrm{T}}\right]$ vs. [Cu] yields a straight line with a slope of $1 / L_{\mathrm{T}}$ and an intercept of $1 / K L_{\mathrm{T}}$ (Figure 4$)$. The calculated repeatability $(n$ $=5)$ was found lower than $10 \%$. 

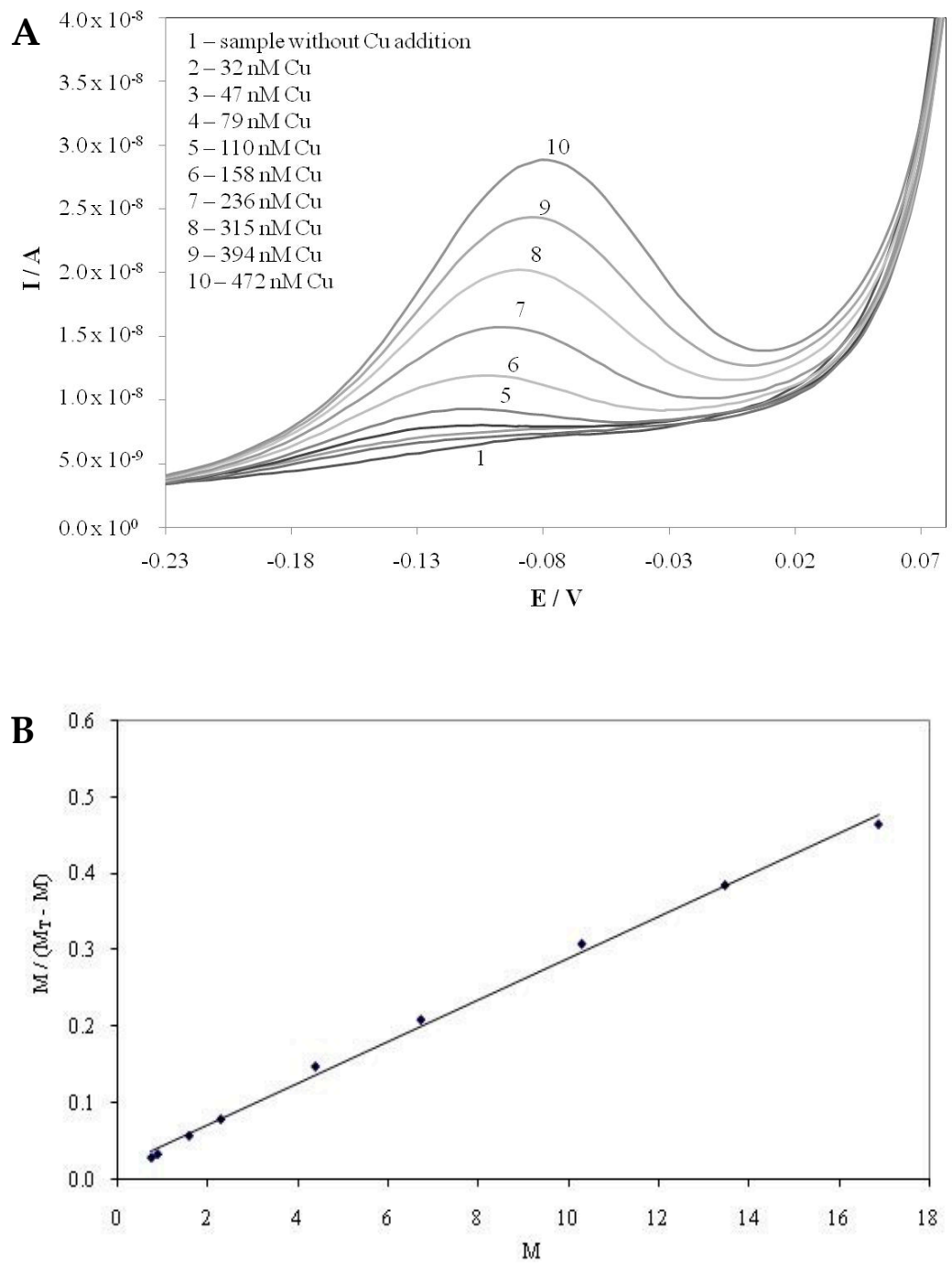

Figure 4. DPASV voltammograms of $\mathrm{Cu}$ ion titrations (A) and Ruzic-van den Berg plot (B) for the balsamic vinegar sample BR5.

\subsection{Trace Metals}

Vinegar samples were digested with $\mathrm{HNO}_{3} 65 \%$ supra pure (Merck, Darmstadt, Germany) with subsequent addition of $\mathrm{H}_{2} \mathrm{O}_{2} 30 \%$ according to Sakellari et al. [27]. For the determination of $\mathrm{Al}$, $\mathrm{As}, \mathrm{Ba}, \mathrm{Cd}, \mathrm{Co}, \mathrm{Cr}, \mathrm{Cs}, \mathrm{Cu}, \mathrm{Fe}, \mathrm{Mn}, \mathrm{Ni}, \mathrm{Pb}, \mathrm{Rb}, \mathrm{Sr}, \mathrm{V}$, and $\mathrm{Zn}$, the digested samples were analyzed through inductively coupled plasma mass spectrometry (ICP-MS) by a Thermo Scientific ICAP Qc (Waltham, MA, USA). Measurements were carried out in a single-collision cell mode, with kinetic energy discrimination (KED) using pure He. Matrix induced signal suppressions and instrumental drift were corrected by internal standardization $\left({ }^{45} \mathrm{Sc},{ }^{103} \mathrm{Rh}\right)$. Measurements were performed in triplicate.

Precision repeatability $(n=5)$ was $<15 \%$ for all trace metals. The LODs (in $\mu \mathrm{g} \mathrm{L}^{-1}$ ) were equal to 0.02 for $\mathrm{Co}$ and $\mathrm{Cs} ; 0.03$ for $\mathrm{Cd}, 0.05$ for As, $\mathrm{Pb}$, and V; 0.10 for $\mathrm{Ba}, \mathrm{Cr}, \mathrm{Rb}$, and $\mathrm{Sr} ; 0.20$ for $\mathrm{Mn}, 0.40$ for $\mathrm{Cu}$ and $\mathrm{Ni}$; 1.0 for $\mathrm{Zn} ; 2.0$ for $\mathrm{Al}$; and 3.0 for $\mathrm{Fe}$ [60]. For statistical calculations, values below the LOD were assigned the limit of detection divided by 2 .

The quality assurance was provided by recovery tests through the analysis of metal spiked samples. Recovery efficiency for spiked sample analysis was $77.8 \%$ for $\mathrm{Zn}, 82.1 \%$ for $\mathrm{Cr}, 88.2 \%$ for $\mathrm{Fe}, 89.2 \%$ for $\mathrm{Pb}, 89.8 \%$ for $\mathrm{Ni}, 90.2 \%$ for $\mathrm{V}, 93.6 \%$ for $\mathrm{Sr}, 95.8 \%$ for $\mathrm{Ba}, 97.1 \%$ for $\mathrm{Mn}, 97.2 \%$ for $\mathrm{Cs}$, $97.5 \%$ for $\mathrm{Cd}, 98.3 \%$ for $\mathrm{Cu}, 104.2 \%$ for $\mathrm{Al}$, and $107.7 \%$ for As. The certified reference materials (CRM) 
ERM $^{\circledR}$-CD281 (rye grass) and BCR No 279 (trace elements in sea lettuce Ulva lactuca) were analyzed and the recoveries for $\mathrm{As}, \mathrm{Cd}, \mathrm{Cr}, \mathrm{Cu}, \mathrm{Mn}, \mathrm{Ni}, \mathrm{Pb}$, and $\mathrm{Zn}$ were in the range $\pm 20 \%$.

\subsection{Organic Carbon (OC) and $p H$}

Total organic carbon (OC) was determined by high temperature catalytic oxidation employing a TOC-5000A Shimadzu analyzer (Shimadzu Scientific Instruments, Columbia, MD, USA). The precision was estimated as the standard deviation between injections and was less than $2 \%$ of the mean.

The $\mathrm{pH}$ of the samples was measured with a Jenway $3310 \mathrm{pH}$-meter (Jenway LTD, Felsted, Dunmow, Essex, UK).

\subsection{Statistical Analysis}

The Kolmogorov-Smirnov and Shapiro-Wilk tests were used to assess the normality of data. Both tests gave $p$ values less than 0.05 and the null hypothesis (that the data are normally distributed) was rejected. Therefore, the non-parametric tests Mann-Whitney U and Kruskal-Wallis were used to statistically compare values between two groups and more than two groups, respectively. Principal component analysis (PCA) was used in order to evaluate any data trends and gain an overview of the relationships among the trace metals examined. PASW Statistics for Windows, Version 24.0, was used as a statistical package (SPSS Inc, Chicago, IL, USA).

\section{Conclusions}

Metal chelation comprises, together with free radical scavenging and reducing capacity, the modes of antioxidant action exerted by plant phenolics. The organic matter in vinegars includes ligands such as polyphenols capable of complexing metal ions. $\mathrm{pH}$ is a factor which strongly influences metal complexation with organics. Due to the low acidity of vinegars, the study of metal complexation is of particular interest.

Copper complexing capacity $\left(L_{\mathrm{T}}\right)$ was determined for the first time in 43 vinegars by differential pulse anodic stripping voltammetry (DPASV). Copper ions were not efficiently "buffered" by the organic matter, since in $21 \%$ of the samples, total $\mathrm{Cu}$ concentrations exceeded the corresponding $L_{T}$ values. The density of $\mathrm{Cu}$ ligands per mass unit of organic matter was found to be higher in balsamic vinegars originating from red grapes compared to those of herbal infusions, coffee brews, and beersas determined in previous studies. A positive correlation of $L_{\mathrm{T}}$ values with the total phenolic content (TPC) of vinegar samples $\left(\mathrm{R}^{2}=0.61, p<0.05\right)$ was found.

Anthropogenic sources, such as the application of fertilizers, and plant protection practices in combination with technological manipulations (e.g., material used during transport, processing, or storage) seem to significantly contribute to the observed concentrations of $\mathrm{Rb}, \mathrm{Zn}, \mathrm{Cd}, \mathrm{Cu}, \mathrm{Mn}, \mathrm{Pb}$, and Cs in vinegars.

Supplementary Materials: The following are available online at http://www.mdpi.com/1420-3049/25/4/861/s1, Table S1: Normalized values of $L_{\mathrm{T}}$ in terms of organic carbon concentration in a variety of beverages, infusions and food additives, Table S2: Trace metals content $\left(\mu \mathrm{L} \mathrm{L}^{-1}\right)$ of vinegars studied (mean value \pm standard deviation), Figure S1: PCA analysis of trace metals in common (A) and balsamic (B) vinegars.

Author Contributions: Conceptualization, V.J.S., N.K., S.K., P.Z. and A.S.; methodology, S.K., A.S., M.P. and N.K.; validation, S.K. and A.S.; formal analysis, S.K. and A.S.; software, P.Z. and M.D.; writing-original draft preparation, S.K., A.S. and N.K.; writing-review and editing, S.K., A.S., V.J.S., P.Z., M.P., M.D. and N.K.; supervision, N.K. and S.K. All authors have read and agreed to the published version of the manuscript.

Funding: This research received no external funding.

Acknowledgments: The authors would like to thank the anonymous reviewers for their valuable comments.

Conflicts of Interest: The authors declare no conflicts of interest. 


\section{References}

1. Plessi, M. Vinegar. In Encyclopedia of Food Sciences and Nutrition, 2nd ed.; Caballero, B., Trugo, L.C., Finglas, P.M., Eds.; Academic Press: Oxford, UK, 2003; Volume 9, pp. 5996-6004, ISBN 9780122270550.

2. Budak, N.H.; Aykin, E.; Seydim, A.C.; Greene, A.K.; Guzel-Seydim, Z.B. Functional properties of vinegar. J. Food Sci. 2014, 79, 757-764. [CrossRef] [PubMed]

3. Paneque, P.; Morales, M.L.; Burgos, P.; Ponce, L.; Callejon, R.M. Elemental characterization of Andalusian wine vinegars with protected designation of origin by ICP-OES and chemometric approach. Food Control 2017, 75, 203-210. [CrossRef]

4. Giudici, P.; Gullo, M.; Solieri, L. Traditional balsamic vinegar. In Vinegars of the World; Solieri, L., Giudici, P., Eds.; Springer: Milan, Italy, 2009; Volume 10, pp. 157-177, ISBN 978-0-470-0865-6.

5. Mas, A.; Torija, M.J.; García-Parrilla, M.C.; Troncoso, A.M. Acetic acid bacteria and the production and quality of wine vinegar. Sci. World J. 2014, 394671. [CrossRef] [PubMed]

6. Ndung'u, K.; Hibdon, S.; Veron, A.; Russell Flegal, A. Lead isotopes reveal different sources of lead in balsamic and other vinegars. Sci. Total Environ. 2011, 409, 2754-2760. [CrossRef]

7. Schumann, K.; Elsenhans, B. The impact of food contaminants on the bioavailability of trace metals. J. Trace Elem. Med. Biol. 2002, 16, 139-144. [CrossRef]

8. Rice-Evans, C.A.; Miller, N.J.; Paganga, G. Structure antioxidant activity relationships of flavonoids and phenolic acids. Free Radical Bio Med. 1996, 20, 233-256. [CrossRef]

9. Mira, L.; Fernandez, M.T.; Santos, M.; Rocha, R.; Florencio, M.H.; Jennings, K.R. Interactions of flavonoids with iron and copper ions: A mechanism for their antioxidant activity. Free Radic. Res. 2002, 36, 1199-1208. [CrossRef]

10. Shahidi, F.; Mcdonald, J.; Chandrasekara, A.; Zhong, Y. Phytochemicals of foods, beverages and fruit vinegars: Chemistry and health effects. Asia Pac. J. Clin. Nutr. 2008, 17 (Suppl. 1), 380-382.

11. Wang, Y.; Ho, C.T. Polyphenolic chemistry of tea and coffee: A century of progress. J. Agric. Food Chem. 2009, 57, 8109-8114. [CrossRef]

12. Brown, P.; Markich, S. Evaluation of the free ion activity model of metal-organism interaction: Extension of the conceptual model. Aquat. Toxicol. 2000, 51, 177-194. [CrossRef]

13. Chito, D.; Galceran, J.; Companys, E.; Puy, J. Determination of the complexing capacity of wine for Zn using the absence of gradients and Nernstian equilibrium stripping technique. J. Agr. Food Chem. 2013, 61, 1051-1059. [CrossRef] [PubMed]

14. Vink, J.P.M. The origin of speciation: Trace metal kinetics over natural water/sediment interfaces and the consequences for bioaccumulation. Environmental Pollution 2009, 157, 519-527. [CrossRef] [PubMed]

15. Plavšić, M.; Krznarić, D.; Branica, M. Determination of the apparent copper complexing capacity of seawater by DPASV. Mar. Chem. 1982, 11, 17-31. [CrossRef]

16. Steinberg, S.M.; Hodge, V.F. Copper complexation by dissolved organic matter in arid soils: A voltametric study. Environments 2018, 5, 125. [CrossRef]

17. Tran, T.; Brown, B.; Nesic, S.; Tribollet, B. Investigation of the mechanisms for acetic acid corrosion of mild steel. In Proceedings of the NACE International, Corrosion Conference \& Expo, Orlando, FL, USA, 17-21 March 2013. Abstract Number 2487.

18. Mazinanian, N.; Odnevall Wallinder, I.; Hedberg, Y. Comparison of the influence of citric acid and acetic acid as simulant for acidic food on the release of ally constituents from stainless steel AISI 201. J. Food Eng. 2015, 145, 51-63. [CrossRef]

19. Ndung'u, K.; Hibdon, S.; Flegal, A.R. Determination of lead in vinegar by ICP-MS and GFAAS: Evaluation of different sample preparation procedures. Talanta 2004, 64, 258-263. [CrossRef]

20. Da Silva, J.C.J.; Cadore, S.; Nobrega, J.A.; Baccan, N. Dilute-and-shoot procedure for the determination of mineral constituents in vinegar samples by axially viewed inductively coupled plasma optical emission spectrometry (ICP OES). Food Addit. Contam. Part A Chem. Anal. Control Expo. Risk Assess. 2007, 24, 130-139. [CrossRef] [PubMed]

21. Fu, L.; Nie, X.; Xie, H.L.; Ferro, M.D. Rapid multi-element analysis of Chinese vinegar by sector field inductively coupled plasma mass spectrometry. Eur. Food Res. Technol. 2013, 237, 795-800. [CrossRef]

22. Buck, K.N.; Ross, J.R.M.; Flegal, A.R.; Bruland, K.W. A review of total dissolved copper and its chemical speciation in San Francisco Bay, California. Environ. Res. 2007, 105, 5-19. [CrossRef] 
23. Sander, S.S.; Buck, K.N.; Wells, M. The effect of natural organic ligands on trace metal speciation in San Francisco Bay: Implications for water quality criteria. Mar. Chem. 2015, 173, 269-281. [CrossRef]

24. Chen, W.B.; Smith, D.S.; Guéguen, C. Influence of water chemistry and dissolved organic matter (DOM) molecular size on copper and mercury binding determined by multiresponse fluorescence quenching. Chemosphere 2013, 92, 351-359. [CrossRef] [PubMed]

25. Karavoltsos, S.; Plavšić, M.; Kalogeropoulos, N.; Kogiannou, D.D.A.; Strrmečki, S.; Sakellari, A.; Dassenakis, M.; Scoullos, M. Copper complexing properties and physicochemical characterization of the organic matter in Greek herbal infusions. Food Chem. 2014, 160, 53-60. [CrossRef] [PubMed]

26. Grigoriou, C.; Karavoltsos, S.; Kaliora, A.; Sakellari, A.; Plavšić, M.; Dassenakis, M.; Kalogeropoulos, N. Electrochemical, photometric, and chromatographic methods for the evaluation of organic matter and bioactive compounds in coffee brews. Eur. Food Res. Technol. 2018, 244, 1953-1961. [CrossRef]

27. Sakellari, A.; Karavoltsos, S.; Plavšić, M.; Bempi, E.; Papantonopoulou, G.; Dassenakis, M.; Kalogeropoulos, N. Copper complexing properties, trace metal content and organic matterphysico-chemical characterization of Greek beers. Microchem. J. 2017, 135, 66-73. [CrossRef]

28. Kostova, I.; Balkansky, S. Metal complexes of biologically active ligands as potential antioxidants. Curr. Med. Chem. 2013, 20, 4508-4539. [CrossRef]

29. Sinanoglou, V.; Zoumpoulakis, P.; Fotakis, C.; Kalogeropoulos, N.; Sakellari, A.; Karavoltsos, S.; Strati, I. On the characterization and correlation of compositional, antioxidant and colour profile of common and balsamic vinegars. Antioxidants 2018, 7, 139. [CrossRef]

30. Alonso, A.; Guillén, D.; Barroso, C.; Puertas, B.; García, A. Determination of antioxidant activity of wine byproducts and its correlation with polyphenolic content. J. Agric. Food Chem. 2002, 50, 5832-5836. [CrossRef]

31. Markoski, M.M.; Garavaglia, J.; Oliveira, A.; Olivaes, J.; Marcadenti, A. Molecular properties of red wine compounds and cardiometabolic benefits. Nutr. Metab. Insights. 2016, 9, 51-57. [CrossRef]

32. Haslam, E. Plant polyphenols (syn. vegetable tannins) and chemical defense - A reappraisal. J.Chem.Ecol. 1988, 14, 1789-1805. [CrossRef]

33. Kennedy, J.A.; Powell, K.J. Polyphenol interactions with aluminum (III) and iron (III): Their possible involvement in the podzolization process. Aust. J. Chem. 1985, 38, 879-888. [CrossRef]

34. McDonald, M.; Mila, I.; Scalbert, A. Precipitation of metal ions by plant polyphenols: Optimal conditions and origin of precipitation. J. Agric. Food Chem. 1996, 44, 599-606. [CrossRef]

35. WHO. Safety Evaluation of Certain Contaminants in Food Arsenic; WHO Food Additives Series: 63; JECFA Monographs 8; WHO: Geneva, Switzerland, 2011; pp. 153-316.

36. WHO. Evaluation of Certain Food Additives and Contaminants. WHO Technical Report Series 983. In Proceedings of the 77th Report of the Joint FAO/WHO Expert Committee on Food Additives, Rome, Italy, 4-13 June 2013.

37. Gupta, S.K.; Vollmer, M.K.; Krebs, R. The importance of mobile, mobilisable and pseudo total heavy metal fractions in soil for three-level risk assessment and risk management. Sci. Total Environ. 1996, 178, 11-20. [CrossRef]

38. Romic, M.; Romic, D. Heavy metals distribution in agricultural topsoils in urban area. Environ. Geol. 2003, 43, 795-805. [CrossRef]

39. Rudnick, R.L.; Gao, S. Composition of the Continental Crust. Treatise on Geochem. 2003, 3, 1-64.

40. Walter, K.H. Manganese Fertilizers. In Manganese in Soils and Plants. Developments in Plant and Soil Sciences; Graham, R.D., Hannam, R.J., Uren, N.C., Eds.; Springer: Dordrecht, The Netherlands, 1988; Volume 33, pp. 225-241.

41. Azzi, V.; El Samrani, A.; Lartiges, B.; Kobeissi, A.; Kanso, A.; Kazpard, V. Trace metals in phosphate fertilizers used in eastern Mediterranean countries. CLEAN - Soil, Air, Water 2017, 45, 1500988. [CrossRef]

42. Provenzano, M.R.; El Bilali, H.; Simeone, V.; Baser, N.; Mondelli, D.; Cesari, G. Copper contents in grapes and wines from a Mediterranean organic vineyard. Food Chem. 2010, 122, 1338-1343. [CrossRef]

43. Senesi, N.; Polemio, M.; Lorusso, L. Evaluation of barium, rubidium and strontium contents in commercial fertilizers. Fertil. Res. 1983, 4, 135-144. [CrossRef]

44. Scoullos, M.; Vonkeman, G.; Thornton, I.; Makuch, Z. Mercury-Cadmium-Lead. Handbook for sustainable Heavy Metals Policy and Regulation, 1st ed.; Springer-Science+Business Media: Dordrecht, The Netherlands, 2001; p. 525, ISBN 978-94-010-3896-6. 
45. WHO. Evaluation of Certain Food Additives and Contaminants. WHO Technical Report Series 683. In Proceedings of the 26th report of the Joint FAO/WHO Expert Committee on Food Additives, Geneva, Switzerland, 19-26 October 1982.

46. Lauchli, A.; Epstein, E. Transport of potassium and rubidium in plant roots. Plant Physiol. 1970, 45, 639-641. [CrossRef]

47. Kot, F.S. On the rubidium and lithium content and availability in the sub-arid south-eastern Mediterranean: Potential health implications. Environ. Geochem. Health 2018, 40, 1841-1851. [CrossRef]

48. Campbell, L.; Fisk, A.; Wang, X.; Kock, G.; Muir, D.C.G. Evidence for biomagnification of rubidium freshwater and marine food webs. Can. J. Fish. Aquat. Sci. 2005, 62, 1161-1167. [CrossRef]

49. Guerrero, M.I.; Herce-Pagliai, C.; Cameán, A.M.; Troncoso, A.M.; Gustavo González, A. Multivariate characterization of wine vinegars from the south of Spain according to their metallic content. Talanta 1997, 45, 379-386. [CrossRef]

50. Navarro-Alarcon, M.; Velasco, C.; Jordal, A.; Terrés, C.; Olalla, M.; Lopez, H.; Lopez, M.C. Copper, zinc, calcium and magnesium content of alcoholic beverages and by-products from Spain: Nutritional supply. Food Addit. Contam. Part A Chem. Anal. Control Expo. Risk Assess. 2007, 24, 685-694. [CrossRef] [PubMed]

51. Troncoso González, A.M.; Guzmán Chozas, M. Metallic contaminants in Andalusian vinegars. Nahrung 1988, 32, 743-748. [CrossRef] [PubMed]

52. Junior, M.M.S.; Silva, L.O.B.; Leão, D.J.; Ferreira, S.L.C. Analytical strategies for determination of cadmium in Brazilian vinegar samples using ET AAS. Food Chem. 2014, 160, 209-213. [CrossRef]

53. Acosta, A.; Diaz, C.; Hardisson, A.; González, D. Levels of Cd, Pb, and Ni in different types of vinegars. Bull. Environ. Contam. Tox. 1993, 51, 852-856. [CrossRef]

54. Acosta-Artiles, A.; Diaz Romero, C.; Hardisson de la Torre, A. Concentration levels of metals in different types of vinegars. Nahrung 1993, 37, 72-73. [CrossRef]

55. Akpinar-Bayizit, A.; Turan, M.A.; Yilmaz-Ersan, L.; Taban, N. Inductively coupled plasma optical-emission spectroscopy determination of major and minor elements in vinegar. Not. Bot. Hort. Agrobot. Clu. J. 2010, $38,64-68$.

56. Ozbek, N.; Koca, M.; Akman, S. A practical method for the determination of Al, B, Co, Cr, Cu, Fe, Mg, Mn, $\mathrm{Pb}$, and $\mathrm{Zn}$ in different types of vinegars by microwave induced plasma optical emission spectrometry. Food Anal. Methods 2016, 9, 2246-2250. [CrossRef]

57. Siavash Saei-Dehkordi, S.; Fallah, A.A.; Ghafari, E. Determination of lead, cadmium, copper, and zinc content in commercial Iranian vinegars using stripping chronopotentiometry. Food Anal. Method. 2012, 5, 767-773. [CrossRef]

58. Ružić, I. Theoretical aspects of the direct titration of natural waters and its information yield for trace metal speciation. Anal. Chim. Acta 1982, 140, 99-113. [CrossRef]

59. Van den Berg, C.M.G. Determination of copper complexation with natural organic ligands in seawater by equilibration with $\mathrm{MnO}_{2}$ : II. Experimental procedures and application to surface seawater. Mar Chem 1982, 11, 323-342. [CrossRef]

60. U.S. Environmental Protection Agency. Definition and Procedure for the Determination of the Method Detection Limit, Rev. 2,40 CFR, 136, App. B. 2016; pp. 1-6. Available online: https://www.epa.gov/sites/ production/files/2016-12/documents/mdl-procedure_rev2_12-13-2016.pdf (accessed on 18 January 2020).

Sample Availability: Samples of the compounds are not available from the authors. 